\title{
Social control in basic sanitation at Guarulhos (SP): the Municipal Council of Urban Policies
}

\author{
Mariana Gutierres Arteiro da Paz \\ Ana Paula Fracalanza
}

${ }^{I}$ Colaborating researcher of LADIS/CCST/INPE; Master's Degree in Public Heath by Universidade de São Paulo (FSP/USP); Doctor's Degree in Environmental Science by Instituto de Energia e Ambiente of Universidade de São Paulo (PROCAM/IEE/ USP), Postdoctor by Escola de Artes Ciências e Humanidades of Universidade de São Paulo (EACH/USP), Postdoctor by Centro de Ciência do Sistema Terrestre (CCST/INPE).

São Paulo/SP - Brasil

${ }^{11}$ Professor at Escola de Artes, Ciências e Humanidades of Universidade de São Paulo (EACH/USP), at Programa de Pós-Graduação em Mudança Social e Participação Política of Universidade de São Paulo (PROMUSPP/USP) and at Programa de Pós-Graduação em Ciência Ambiental of Instituto de Energia e Ambiente of USP (PROCAM/IEE/USP).

São Paulo/SP - Brasil

\begin{abstract}
Water supply and sanitation sector in Brazil has a centralized background. The Federal Law no.11.445, in 2007, brings the possibility of participation and social control on sector; and mechanisms to decentralized decision-making and to include several sectors on water supply and sanitation sector for integrative governance. Therefore, this paper aims to evaluate incorporation of water supply and sanitation on Municipal Council of Urban Policy in Guarulhos, SP, between 2015 and 2017; and to evaluate social participation according to environmental justice and water governance. This research focuses on Council's meetings. The studied Council did not deal with basic sanitation actions, even at a time of water supply crises, and was mainly based on issues related to the revision of the Municipal Master Plan. The imposition of social control of water supply and sanitation did not contribute to the social construction of the process.
\end{abstract}

Keywords: social control, water supply and sanitation, water governance.

São Paulo. Vol. 23, 2020

Original Article

DOI: http://dx.doi.org/10.1590/1809-4422asoc20190019r1vu2020L4AO 


\section{INTRODUCTION}

Brazil has shifted during the last three decades from an institutionally fragmented administration to an integrated and decentralized legislation. (AVRITZER, 2008; JACOBI, 2009; GURGEL \& JUSTEN, 2013). The promulgation of Law no. 11.445/2007 happened within this context, instituting national guidelines for basic sanitation and for the Federal Policy on Basic Sanitation, which presents in its text a favorable environment for integration and an area to widen peer community, which is fit to the complexity of the matter (HOVE, 2000; JACOBI; GÜNTHER \& GIATTI, 2012). Considering the analysis of participative approaches in the formulation of environmental policies, using as examples participative approaches in Europe, Hove (2002) concludes that:

Participatory approaches are institutional settings which bring togeth-
er various actors at some stage of the environmental policy-making
process. They include negotiations, co-operative processes, and
multi-stakeholders approaches of different types, at different levels,
and of different degree of formality. [...] participatory approaches do
constitute effective tools of governance in the context of sustainable
development objectives (HOVE, 2000, p. 471)

Hove (2000) emphasizes "the need for coordination across policy areas and integration of environmental action into multiple sectors of society" (HOVE, 2000, p. 464), and that such coordination demands representative participation by the segment's interests on problem-solving processes. Integrated action between basic sanitation and water resource areas, and the participation are interdependent (PAZ \& JACOBI, 2015) and are therefore needed to deal with water and sanitation matters, to issues related to health, housing, and so many other areas managed by Public Administration (HELLER, 2015; PAZ \& JACOBI, 2015; PITERMAN; HELLER \& REZENDE, 2013).

Participation and social control on public policies are devices that decentralize the decision-making power, and that include many society segments on the debate of an issue, thus enabling integrative governance. In this sense, this article aims to assess the incorporation of basic sanitation on the Municipal Council of Urban Policies (CMPU) at Guarulhos, São Paulo, Brazil, which was subjected to social control in basic sanitation; and to assess the participation in basic sanitation according to the precepts of water justice and governance.

\section{Methodology}

A case study was used to asses participation and social control in basic sanitation at Guarulhos, São Paulo, Brazil, since it allows understanding the complexity of social phenomena (YIN, 2005). The object of study was the Municipal Council of Urban Policy (CMPU) in the municipality, which is the Participative Institution (PI) that exerts social control of the municipality's basic sanitation, as established in the Federal Law no. $11.445 / 2007$ and its regulations, and to establish social control procedures and mecha- 
nisms, according to the article 9, VI (BRAZIL, 2007).

Thus, records of regular and extraordinary sessions in 2015, 2016, and 2017 were analyzed, in a total of 38 analyzed records, aiming to verify how the issues of basic sanitation has been introduced in this PI. The choice for this period considered the date when this area was instituted as a social control council for basic sanitation (December 2014). The content of the record was analyzed, focusing on three groups: present and absent representatives; reoccurring general themes, such as master plan and zoning; and matters related to basic sanitation (water supply, sanitary sewage, urban clean-up, and solid residue and urban rainwater treatment).

As a complement, seven council members were interviewed (four civil society representatives and three public power representatives) and the authors took part in nine Council meetings in 2017. The number of standing members is 13 civil society entities and 11 public power ones, with a total of 24 representatives. The minimum quota is a third of standing members, that is, 8 present representatives. The average of present representative in the meetings in 2015, 2016, and 2017 was 14 . All seven interviewed people are among the actors most present in Council meetings from 2015 to 2017 (minimum attendance of 50\%), according to the presence in the records. Among the most present ones, only one actor was not interviewed.

Data from records, interviews and participation in the meetings were triangulated. The results observed were considered and the themes were analyzed based on the literature on environmental justice and water governance, and on studies on social control over basic sanitation in Brazil.

\section{Water governance and justice}

This study is based on the complexity of water governance and its dialogue to Environmental Science, and its consequent need for integration and interdisciplinarity, considering that issues related to water resources involve many disciplines (CASTRO, 2007). The development of interdisciplinary approaches, contributing for the development of governance and water management practices based on sustainability and social justice, is one of the most pressing challenges of water governance at the 21st century (CASTRO, 2007).

The concept of governance that used to be related to government processes, to "governing", nowadays refers to a new form of ruling, more cooperative and dealing with problem-solving as a collective and for the promotion of public wellbeing (MAYNTZ, 2001). Dietz, Ostrom and Stern (2003) approached the difficulty in governing complex environmental systems based on governance, since it involves difficult decision-making, with value and interest conflicts; and it tends to "escape" governance rules, thus pointing to the need to develop institutional arrangements to help establish conditions address the main challenges of governance in the absence of ideal conditions.

Considering the need to strengthen relations between society and the government, to work the water issue in cooperation among areas and society's segments, and 
the conflicts inherent to the administration process, Castro (2007), considers that water governance is essential to manage all contradictions emerging from the water issue. Water governance refers, among others, to the allocation of rights - right to water and technology and right to participate in the decision-making process - and to water resources, maintenance and investment funds, making room for groups of interest and social power (MOLLINGA, 2008).

Based on a critical approach to this concept, Castro (2007) emphasizes that governance is not a strategy, but a system for interaction among actors, a political process. One of the key elements of governance is the creation of an institutional and administrative board, where people with different interests can discuss and agree in cooperate and coordinate their actions.

Besides action cooperation and coordination, the concept of governance is inclusive regarding the equitable appropriation of water resources (MOLLINGA, 2008; FRACALANZA; JACOB \& EÇA, 2013), especially in cases of environmental injustice, which are perceived "as the growing lack of natural resources and destabilization of ecosystems affect different social groups or geographical areas unequally and many timesunfairly" (IORIS, 2009, p. 389).

Environmental segregation and social inequality remind the difficulty in accessing infrastructure and urban services, with unequal offer of public environmental sanitation services, considering the tendency for low-income population to be installed areas of higher socio-environmental vulnerability, with bigger exposure to floods and landslides; and with inadequate public urban services such as environmental sanitation (FRACALANZA; JACOB \& EÇA, 2013).

The concept of environmental sanitation is wide, and it considers the set of socioeconomic actions aiming at levels of environmental healthiness through potable water supply, sanitary collection and disposal of solid, liquid and gas residue, promotion of sanitary discipline for the use of soil, urban drainage, control of infectious diseases and other specialized services and works, aiming to protect and improve the conditions for urban and rural life (BRAZIL, 2015, p. 19).

Besides the spatial exclusion from public environmental sanitation services, Castro (2013) presents factors that belong to the social dimension - related to different water consumption patterns between countries and regions - as factors that influence the administration of Water and Sewage Services (WSS) and that have been historically minimized or overlooked. The author emphasizes that analyzes of systemic conditioning factors ${ }^{1}$ of WSS do not always consider the real complexity of factors such as social and structural inequality, differences in consumption habits, and weather or technological restrictions; even with the growing recognition that the main challenges for WSS are not technical or physical-natural, but social ones (CASTRO, 2013).

However, water in Brazil has been considered by the legislation as a public domain

1 - Systemic conditioning factors are the socioeconomic, political and cultural processes that largely structure and determine the options of public policies (HELLER \& CASTRO, 2007, p. 287). 
good, and, for that reason, should be offered to all population in proper quality and quantity (FRACALANZA; JACOB \& EÇA, 2013). Within the scope of the New Water Culture principles, Mulas (2013) agrees with the view that WSS are an essential human right by affirming that:

the universal access to environmental sanitation services, which are essential for life in a civilized society, constitute a social citizenship right and it cannot be subjected to market criteria, which requires significant changes in institutions and organizational processes involved in the administration and sanitation services (MULAS, 2013, p. 98).

In this sense, the promotion of environmental sanitation for low-income population should be a priority (FRACALANZA; JACOB \& EÇA, 2013), and the access to these services is imperative to break with poverty cycles (RAZZOLINI \& GÜNTHER, 2008). However, to level the disparities found in Brazil, one needs to ponder on natural dimensions, such as water supply, and on policies that are able to convey many interests in the use of water (RIBEIRO, 2009), such as water resource, inhabitation, and basic sanitation policies.

Ribeiro (2009) highlights the importance of social participation in policies related to water for its governance, and emphasizes social mobilization, the State's capacity to assimilate external decisions, and the creation or existence of judicial tools that enable legitimate social participation. In the Brazilian scenario, the conditions needed for water governance exist, the question is whether social participation does represent the incorporation of society in water resource administration (RIBEIRO, 2009).

While progressing toward water sustainability, Ribeiro (2009) considers that political agreements are necessary to guarantee meeting such diverse demands from distinct water users, between small and big users; for that reason, the water governance is needed, since it considers the participation of different actors, segments and knowledge fields in society.

Indeed, it is known that even with such participation, there are still social actors excluded from the participation in water governance, since they are not set as organized civil society; however, the Legislation on water resources and basic sanitation in Brazil has advanced by establishing the participation of segments of organized civil society and social control through Councils and Committees. This will be verified below, in the case of basic sanitation.

\section{Participation and social control in basic sanitation}

The notion of participation is related to democracy and to the existence of a public sphere. In Latin America, the construction of democracy arises in the 1990s and contributes to strengthen the construction of citizenship and participation (AVRITZER, 2008; 2013). In Brazil, the milestone of this process was the promulgation of the Federal Constitution, in 1988. Brazil's recent democracy is highlighted by the appearance of Participative Institutions (PI), which, for Avritzer (2008, p. 45), are "the different ways 
of incorporating citizens and civil society associations in the debate on policies", such as "participative budgets, policy councils, and municipal master plans" (AVRITZER, 2008, p. 43).

Avritzer (2008) presents three ways of participating in political decisions: bottomup participative designs, such as the participative budget in Brazil; the process in which citizens do not take part in decisions, but are invited to publicly ratify them; and the object of this study: "a process of power-sharing, that is, through the constitution of an institution in which state and civil society actors take part simultaneously" (AVRITZER, 2008, p. 46).

Social control also appears as a response to the discussions on the limitations of representative democracy, related to:

the suspicion regarding government authorities, considered as the influence of big business, the bureaucratization and implementation of technology in the decision-making process, negotiations and pressure by interested groups and lobbies over authorities, as well as other aspects that make the formulation of public policies and its consequences doubtful (GURGEL \& JUSTEN, 2013, p. 359).

With the discreditation of the public apparatus, the idea of public participation and social control ${ }^{2}$ arises (GURGEL \& JUSTEN, 2013). As social participation widens the influence capacity over the many decision-making processes in all levels of social activities and institutions, it is characterized as an important tool to strengthen social control (JACOBI, 2009).

Moraes (2013) considers social control as a new concept, dealing with the joint action of segments of organized civil society on the administration of public policies aiming to control how they meet social demands and interests; it refers, thus, to civil society's capacity of interfering on public administration and guiding the State's actions and expenses, always with a view on the collective interest. To this end, mechanisms and tools are needed to guarantee the participation in all service phases ${ }^{3}$ : formulation; planning; financial administration; monitoring; and evaluation (MORAES, 2013). For this perspective, social control is connected to the democracy established in the 1988 Federal Constitution.

Strengthening mechanisms for sector policies' control widens the possibility for the constitution of democratic subjects in the dialogue to public policies, promoting co-responsibility (JACOBI, 2009), and it is a mechanism foreseen in the concept of water governance, along with the constitution of participative public agents (JACOBI; GÜNTHER \& GIATTI, 2012). Hoppe (1999) also points out the need bring community closer to discussions, with a bigger focus on political processes, claiming responsibility

2- Different from the notion of "social control" used by the field of public safety, in which the State control society, here, "social control" means the control exerted by society over the public apparatus (GURGEL \& JUSTEN, 2013).

3 - Public basic sanitation services, foreseen in Law no. 11.445/2007, are the set of measures taken for water supply, basic sanitation, urban clean-up, and solid urban residue treatment and rainwater treatment in urban areas (BRAZIL, 2007). 
not only for policymakers, but for society in democratic countries. By corroborating to the matter of quality in participation, the author also expresses concern regarding the knowledge of issues and political processes, as well as the direct relation to the mobilization of knowledge in politics (HOPPE, 1999).

Social participation on public matters, as basic sanitation and environmental issues, is increasingly discussed in the context of environmental governance due to the complexity, uncertainty, long and spatial time scale, and the irreversibility of many problems (HOVE, 2000). Therefore, responsibility and impacts can be diffuse, thus the importance of the wide participation of the ones involved/affected by the issue (HOVE, 2000). More than simply expanding participation, the uncertainty and complexity demand the action of many actors from different levels, segments, and origins/experiences/fields of action involved in the process (HOVE, 2000).

Following the movement of democratizing public policies in Brazil, the Law of National Guidelines for Basic Sanitation, enacted in 2007, brings social control in the administration of public basic sanitation services as its main change. Social control prescribes the action of society in all following phases of sanitation policies: policy formulation; action planning; services; and service evaluation (MORAES, 2013).

The legitimacy of participative processes also deserves attention, which is highlighted Lavalle and Vera (2011) and Hove (200). On the one hand, for Hove (2000), participation is a factor that contributes to legitimize the decision-making process, as a contribution for more efficient solutions, guaranteeing a compromise to the implementation. The author considers that:

[...] a participatory process allowing for a wide representation of actors can in principle improve the mobilisation of individual and group energies as they gain a greater sense of shared responsibility by becoming part of the problem-solving process, and as a higher legitimacy content is attached to the process itself (HOVE, 2000, p. 464).

On the other hand, Lavalle and Vera (2011) question the legitimacy of democracy regarding representative government, "as well as the legitimacy within practices of political mediation of civil society actors" (LAVALLE \& VERA, 2011, p. 124). Decentralizing the administration does not guarantee society representation (GURGEL \& JUSTEN, 2013; PITERMAN; HELLER \& REZENDE, 2013). Therefore, Piterman, Heller and Rezende (2013) observed, in a study developed in Minas Gerais' municipalities, the incapacity of the participation process in exerting social control over basic sanitation.

The organization of collegiate instances for social control of sanitation foresees the representation of five groups, according to article 47 of Law no. 11.445/2007, namely: service holder; government bodies related to the area; public basic sanitation service providers; service users and technical entities; civil society and consumer protection organizations, related to the segment (BRAZIL, 2007). This configuration of public administration, with collegiate instances and multi-actors, "increases the chances of obtaining high representative levels among interacting actors" (PITERMAN; HELLER 
\& REZENDE, 2013, p. 1190) and is seen as a new form of cooperating and negotiating in face of water use conflicts involving multiple sectors or actors (WARNER, 2005). Although governance is seen as a challenge, the dialogue among interested parts, technical specialists, and scientists has demonstrated good results (DIETZ; OSTROM \& STERN, 2003). However, depending on the segments of representation, there is a bigger representation of government agents and private actors to the detriment of civil society in participative processes (FRACALANZA, 2017).

Lastly, the importance of democratizing the regulation process with the participation of civil society and social control of public sanitation services is highlighted as a way of expanding service quality, as well as its universalization (JACOBI, 2009). It is necessary to understand the mechanisms of social control implemented in the basic sanitation area, the actors involved in the process, the content discussed, and the impact of this control on the municipal basic sanitation policy in order to analyze its outreach and contribute to improving it, considering the studies (AVRITZER, 2007; LAVALLE \& VERA, 2011; GURGEL \& JUSTEN, 2013; HELLER \& REZENDE, 2013) that highlight the difficulty in keeping legitimate participative instances.

\section{Case study: the Council of a São Paulo municipality}

The municipality of Guarulhos, SP, is in the Alto Tietê River Basin and in the Metropolitan Region of São Paulo (RMSP). Its population is estimated in 1,349,113 inhabitants in 2017, with high demographic density, 3,834.51 hab/km2 in 2010 (IBGE, n.d.).

The Water and Sewage Service provider is a municipal autarchy (Guarulhos), the Serviço Autônomo de Água e Esgoto (SAAE - Autonomous Water and Sewage Service). According to the last IBGE census, in 2010, the level of households with water supply was 97.6\% (IBGE, 2011). Currently, SAAE declares to supply $99.84 \%$ households (SNIS, n.d.). Of the distributed potable water, $13 \%$ is produced by SAAE and $87 \%$ of it is acquired from Sabesp (SAAE, n.d. a). For that reason, the municipality faces problems with water supply ever since the water governance crisis in the RMSP, which begun in 2013. In March 14, 2014, the municipality initiated a system of rotation in the provision of water supply, with 18 hours with provision and 30 hours without it, due to the reduction in the water provision by Sabesp, for more the a million of the 1.3 million inhabitants (SAAE, n.d. $b^{4}$ ). This rotation system was reduced in January 2017 and was shifted to 16 hours of water provision and 8 hours without it (SAAE, n.d. b). Proper water supply should be regular, with no intermittence in the process (SNSA, 2013; HELLER, 2015).

Regarding public sanitary sewage services, in $2017^{5}, 88 \%$ of sanitary sewages were collected and $42 \%$ of it were efficiently treated with $96 \%$ removal of organic material (CETESB, 2018). Considering that Guarulhos has an increased population and is located upstream Tietê River in relation to São Paulo, its remaining polluting load of 46,921 kg of BOD/day (CETESB,

4- The period when the rotation of water provision was intensified (18 hours with provision and 30 hours without it) is the same when Guarulhos had debts with Sabesp and, after an agreement for the payment, the rotation shifted to 16 hours of water provision and 8 hours without it (SAAE, n.d. b).

5 - The percentage of population supplied with sewage collection and treatment services was registered by CETESB based on 2017 data provided by the municipalities or service providers (CETESB, 2018, p. 77). 
2018) is relevant for the Alto Tietê River Basin and, consequently for São Paulo's metropolis.

\section{The Municipal Council of Urban Policy and Social Control of Basic Sanitation}

In 2007, the municipality of Guarulhos, SP, created the Municipal Council of Urban Development (CMDU), of advisory and deliberative character, and the Municipal Fund of Urban Development, through the Law no. 6.253, of May 24, 2007. This Council's responsibilities, at that moment, according to its article 2 , were

I - debate the municipality's urban development policy; II $\neg \neg-$ monitoring the implementation of the Master Plan, analyzing and deliberating on issues related to its application; III - debating and opining on the proposal of changes to the Master Plan, Zoning Law, and to the Code of Urban Building and Licensing, as well as suggesting general rules for urbanistic law; IV - articulating actions by the Municipal Councils related to urban policy, aiming to integrate and combine policies for transportation, inhabitation, environment, protection to historical and cultural heritage, and use of soil for the promotion of full development of social function of the city; $\mathrm{V}$ - monitoring planning and the policy for urban development in the municipality; VI - debating, suggesting guidelines, and monitoring the application of the Municipal Fund for Urban Development - FMDU; VII - creating technical chambers; VIII - designing and approving its internal regiment (GUARULHOS, 2007).

At its creation, the objectives were related to the City Statute. However, to fit itself to the Law no. 11.445/2007, which established national guidelines for basic sanitation, the Municipality used the CMDU area to fulfill the collegiate function of social control of public services and basic sanitation - water supply, sanitary sewage, urban clean-up, and solid residue and urban rain water treatment -, using the Decree no. 32.360, of December 29, 2014, including as the Council's responsibility social control over basic sanitation, according to the article 1 :

The Municipal Council of Urban Development now exerts, in an advisory and propositional character, the role of collegiate body for social control of public basic sanitation service, in the terms of article 47 of Federal Law no. 11.445/2007 (GUARULHOS, 2014).

In 2016, the Council underwent another change, with Law no. 7.490, of July 07, 2016, which changes its name to Municipal Council of Urban Policies (CMPU), its current name; and changes the advisory and deliberative character to advisory only, according to article 1: The Municipal Council of Urban Policies is created, having advisory character (GUARULHOS, 2016). Its responsibilities were maintained, with the inclusion of other urban policies in the articulation of the Council's actions (art. 2): 
IV - articulating the actions by Municipal Councils related to urban policy and participative budgets, aiming to integrate and align policies regarding transportation, housing, environment, environmental sanitation protection to cultural and historical heritage, and use of soil for the promotion of the full development of the city's social functions (GUARULHOS, 2016).

During the studied period, from 2015 to 2017,39 regular and extraordinary meetings were carried out, 16 in 2915, 12 in 2016, and 11 in 2017. The representatives during this administration were a standing member and a substitute of the Secretaries of the Municipality, of the City Council, and of the Organized Civil Society (Chart 1).

\section{Chart 1. Bodies represented in the Council according to segments}

\begin{tabular}{|c|c|c|}
\hline Legislative Power & Public Power & Civil Society \\
\hline 2 Councilmen & $\begin{array}{l}\text { Coordination of Policies for } \\
\text { Disabled Persons and Persons } \\
\text { with Reduced Mobility } \\
\text { Autonomous Water and } \\
\text { Sewage Service } \\
\text { Service of Legal Matters } \\
\text { Secretary of Economic Deve- } \\
\text { lopment } \\
\text { Secretary of Urban Develo- } \\
\text { pment } \\
\text { Secretary of Housing } \\
\text { Secretary of Environment } \\
\text { Secretary of Construction } \\
\text { Works } \\
\text { Secretary of Public Services } \\
\text { Secretary of Transportation } \\
\text { and Traffic }\end{array}$ & $\begin{array}{l}7 \text { Associations and Social } \\
\text { Movements } \\
5 \text { Professional Associations } \\
3 \text { Municipal Councils } \\
3 \text { Environmental Entities } \\
2 \text { Trade Unions } \\
1 \text { University }\end{array}$ \\
\hline
\end{tabular}

Source: Designed by the authors based on the meetings' records.

The municipality of Guarulhos currently has, in its governmental structure, 19 secretaries and 10 municipal sub-secretaries. Of these, 9 participated in CMPU meetings during the studied period. Considering SAAE as part of the Public Power, there were 10 municipal bodies participating in Council meetings. According to Avritzer (2008), the structure of municipal councils does not incorporate a wide number of social actors ( $\mathrm{p}$. 46), being restricted to elected representatives, who often participate for many consecutive terms. In the case of the CMPU, councilors may not represent the range of social actors interested in participating in the discussions on public basic sanitation services in the Municipality. This could be observed in another study focused on that.

Even though the spots for civil society were kept the same, there was an increase 
in the frequency of civil society representatives in the meetings between 2015 and 2017, which was observed in the records. Their percentual representativity increased from $40 \%$ of meeting participants in 2015 to 65\% in 2017 (Figure 1). This representativity can also be seen by the interviewee's analysis: when questioned "what is social control in basic sanitation?", only representatives of civil society recognized the concept.

The Secretary of Urban Development was the most frequent public body in the meetings in absolute presence numbers (Figure 2), and which had representatives in all meetings, besides having presided CMPU.

Figure 1. Percentage of segments present in CMPU meeting in 2015, 2016, and 2017
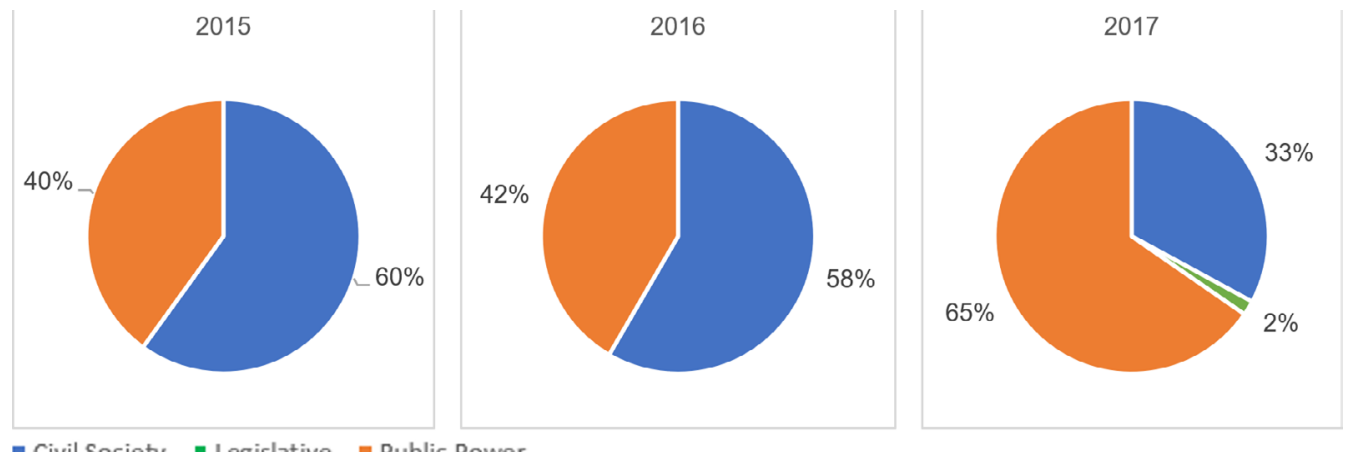

- Civil Society - Legislative = Public Power

Source: Designed by the authors based on meeting records.

The entities of civil societies that were most present were the ones related to social movements (Figure 2), following the tendency observed by Avritzer (2013) in Brazilian Participative Institutions, in which community associativism was highlighted ever since the country's democratization. The Environmental Entity and Professional Classes were also highlighted.

The represented entities are related to the most discussed topics in Council meetings. Since the analyzed period comprised the planning of revising the Master Plan and its effective revision (Figure 3), the increase in the presence of Civil Society (Figures 1 and 2) and the presence of representatives from other Municipal Councils (Figure 2) were relevant and coherent to the process. 
Figure 2. Number of participations of entities represented at CMPU, in 2015, 2016, and $2017^{6}$

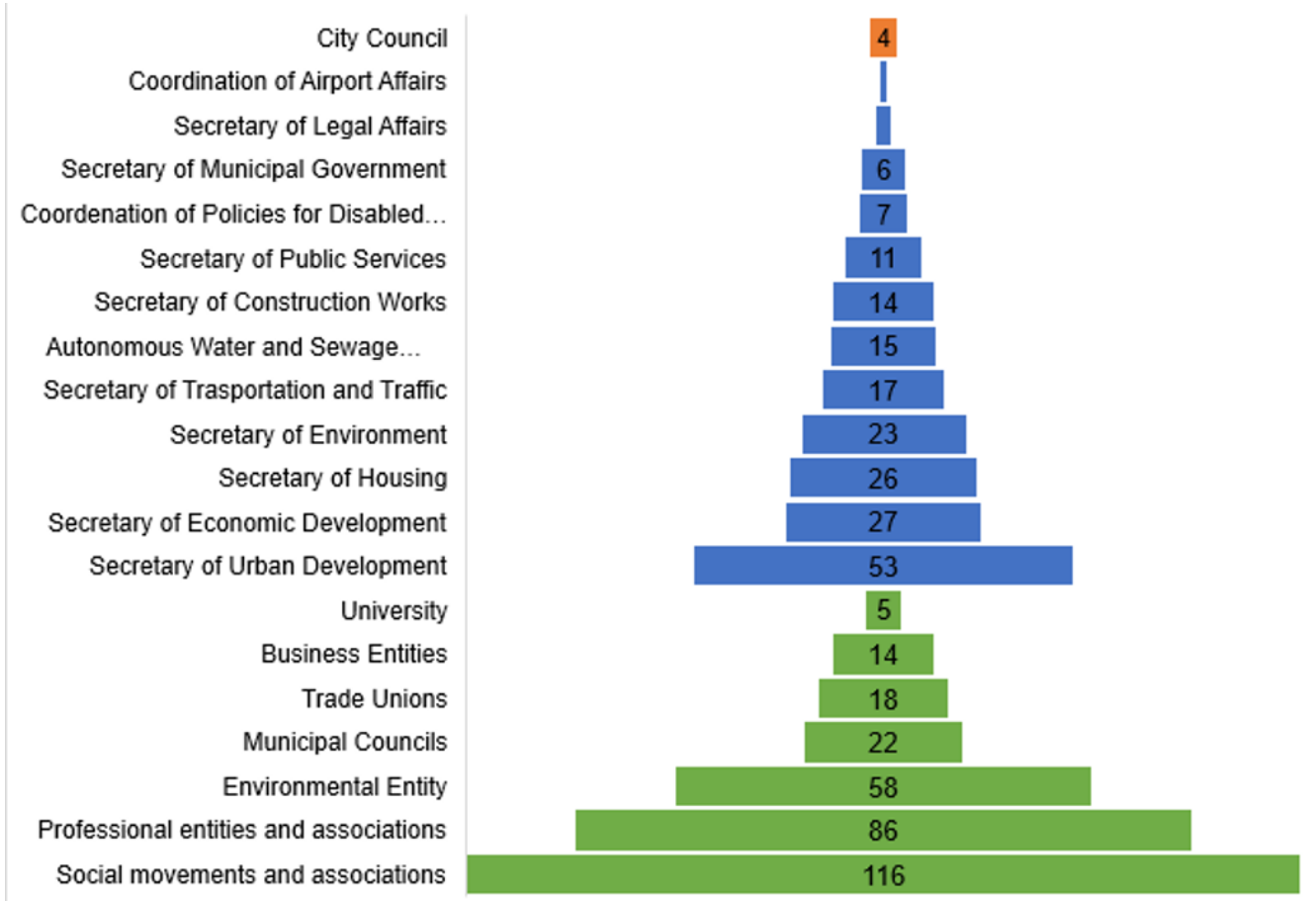

" Civil Society = Legislative = Public Power

Source: Designed by the authors based on meeting records.

Issues related to basic sanitation at CMPU were the presentation by the Regulating Body for Public Basic Sanitation Services of Guarulhos ${ }^{7}$ (AGRU), the Council as an area to exert social control over public basic sanitation services at the Municipality in a descriptive and introductory manner. The second moment happened during the presentation of the Plan for Integrated Urban Development (PDUI), having as one of its work axis Sanitation and Water Resources in the context of RMSP. This explains the reason why only one of the seven interviewees knew that the Council is the place for social control of public basic sanitation services, even though the interviewed people have been to more than $70 \%$ of Council meetings. However, it comes as a surprise that most interviewees (5 out of 7) believe that CMPU is an adequate PI to deal with basic sanitation issues.

6 - The number of participation of entities represented at CMPU was calculated in relation to the sum of presences for each segment during the whole period, to identify which segments were most present at Council meetings and compare numbers to Avritzer's publication (2013).

7 - This body was closed due to a decision by the Federal Supreme Court minister Ricardo Lewandowski in 2017, claiming that the law which created the body in 2012 is unconstitutional. The Decree to close it was issued in March 28, 2018 by the mayor, and its effective closure happened in June 2018. 
Figure 3. Total frequency of issues discussed at CMPU meetings in 2015, 2016, and 2017

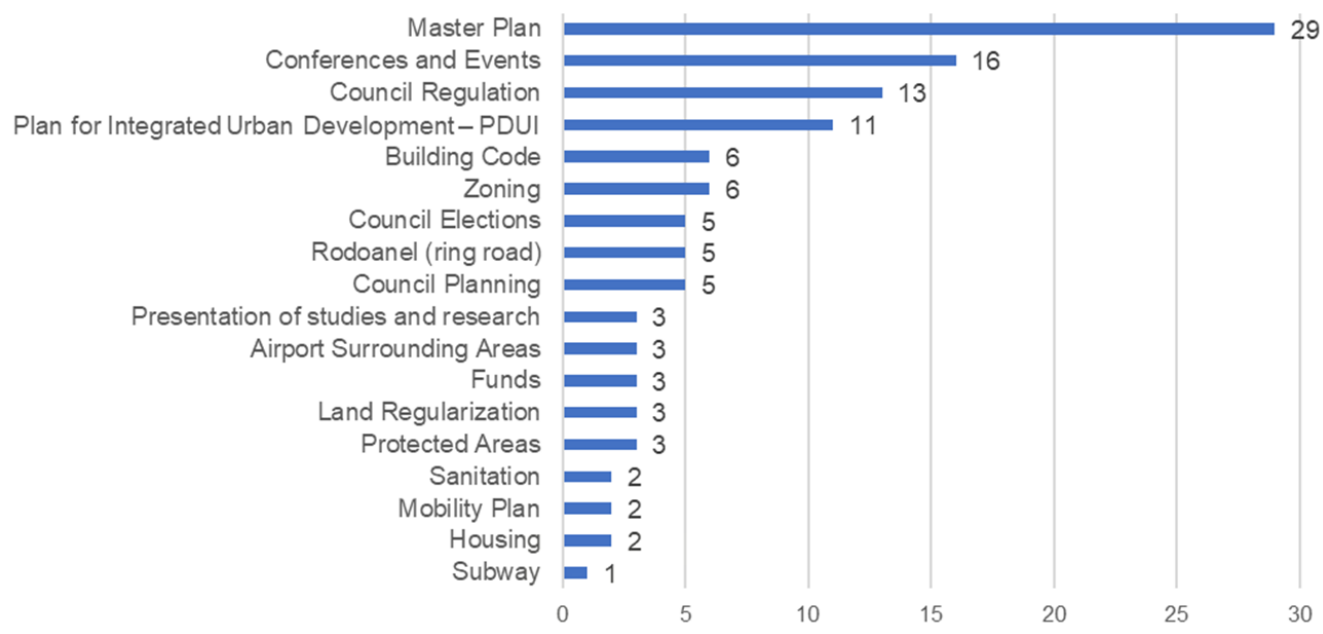

Source: Designed by the authors based on meeting records.

The way this Council attribution was instituted and the councilors' answers showed that this policy was imposed, a characteristic top-down policy for a PI that, at that moment, or due to the way it was imposed, did not present the propensity to deal with basic sanitation issues, even though many authors observe the relation between development and urban policy and the basic sanitation area (HELLER, 2015; PAZ \& JACOBI, 2015; PITERMAN; HELLER \& REZENDE, 2013). That is also seen among interviewees, who mention the centralizing discourse as the main obstacle for the Council to fulfill its attribution of a social control organ. Avritzer (2008, p. 46) lists, as one of the characteristics of councils and collegiate organs, sanctions when the participative process is not implemented, as the case of the studied PI, since the social control over basic sanitation has substituted the implementation of the collegiate established by Law no. 11.445/2007.

This fact was also highlighted by interviewees, since some of them knew that the social control happened through CMPU. Others, who confused it with education and community mobilization actions, said that schools had a central role in raising awareness about the proper use of public basic sanitation services. The interviewee who was aware of social control said it was never discussed, and that the Municipal Basic Sanitation Plan was designed with no participation from civil society. Some interviewees also said that this Council was born from the need of the cities' conference, and that, in Guarulhos, social demand asks for housing.

Social control and participation processes can be more effective even designed by the actors involved in the process. It is interesting to note that the observed period followed the water supply crisis in the Municipality, and that this issue was not approached or discussed by the agenda (MORAES, 2013; PAZ \& JACOBI, 2015). If, on the one hand, the process must be constructed among actors; on the other, a demand can emerge and be worked on, so that actors may see the relation, for example, among water supply; sewage 
drainage and collection; and other issues approached by the Council.

Decentralizing the administration does not guarantee quality in civil representation (GURGEL \& JUSTEN, 2013; PITERMAN; HELLER \& REZENDE, 2013). However, the participation in the area of basic sanitation is recent and poses challenges for its implementation and specially for legitimizing the process. Thus, in the current context, local powers need to organize and plan their future sanitation actions aiming to meet legal premises (PITERMAN; HELLER \& REZENDE, 2013, p. 1181).

Just as in other studies (PAZ \& JACOBI, 2015; PITERMAN; HELLER \& REZENDE, 2013), it was observed that public basic sanitation services are still not discussed in CMPU meetings, even in delicate moments for the are in the Municipality, with the rotation system in water supply. The existence of this instance for social control was not enough for such control to happen.

Management, when limited to technical-scientific and economic requirements of services provided for the population, does not guarantee efficacy and efficiency in the area, demanding the incorporation of public policies that look for participation mechanisms and for the involvement of population in the administration and decision-making process. The motivation and skill of local communities for the maintenance of public basic sanitation services contribute greatly for success in the service (PITERMAN; HELLER \& REZENDE, 2013). However, there is still a long path to go in order to guarantee the access of users and civil society in the decision-making process in water administration.

For most countries, public participation is restricted to gaps in regulations to evaluate the economic efficiency of public investment and to rigid regulations that only legitimize actions in the defense of individual economic interests, besides other factors, such as limited social conditions (SOLANES \& JOURAVLEV, 2005). On the other hand, participative planning, despite careful and well-intentioned, does not erase frustration and conflicts that inevitably follow spatial planning for many ends (WARNER, 2005).

\section{Concluding remarks}

The access to public basic sanitation services in Brazil is still inequal. To balance these disparities, it is important for basic sanitation policy to be treated along with other urban policies. Besides the need to integrate these policies, social participation in environmental and water governance is a necessary tool for including the needs of each territory, and to legitimize State actions.

In Brazil, the conditions for water governance exist, what one needs to know is whether social participation represents the incorporation in water administration of the demands of population, specially of those who are excluded from quality and enough water supply.

The municipality of Guarulhos has many relevant issues to be solved in basic sanitation, such as the low coverage of sewage collection and treatment, and the crisis in water supply, with a long rotation period alternating day of supply.

The council had constant meetings, significantly frequent in relation to many gov- 
ernment segments, as well as civil society ones, and the central theme - development and urban policy - was coherent to the basic sanitation area. Councilors saw this Participative Institution as the proper place to deal with basic sanitation issues, however, a collective construction work within the Council was lacking, so that councilors could understand the need to deal with basic sanitation along with other issues, such as the Master Plan, zoning, land regularization, and other issues discussed in meetings.

Yet, these issues were not presented or discussed at the Council, since the basic sanitation theme was not appropriated by the councilors. Despite counting on representatives from many government bodies, Legislative, and civil society, this Participative Institution has not been developing its social control role in the basic sanitation area; and, while the model for the administration of public basic sanitation services are still far from environmental governance, equality in these services remains even more distant from reality.

\section{Acknowledgment}

To PNPD / CAPES for the postdoctoral scholarship; to the Thematic Project "Resilience and vulnerability at the urban Nexus of food, water, energy and the environment (ResNexus)" (FAPESP Process Number 2015-50132-6) for resources to carry out the field research; and to the members of the Municipal Council for Urban Policy of the Municipality of Guarulhos.

\section{References}

AVRITZER, L. Conferências nacionais: ampliando e redefinindo os padrões de participação social no Brasil. Texto para Discussão. Brasília: IPEA - Instituto de Pesquisa Econômica Aplicada, 2013.

. Instituições participativas e desenho institucional: algumas considerações sobre a variação da participação no Brasil democrático. Opin. Publica, Campinas, v. 14, n. 1, p. 43-64, jun., 2008.

BRASIL. Lei 11.445 de 05 de janeiro de 2007. Estabelece as diretrizes nacionais para o saneamento básico, altera a Lei no 6.766, de 19 de dezembro de 1979, a Lei no 8.036, de 11 de maio de 1990, a Lei no 8.666, de 21 de junho de 1993, e a Lei no 8.987, de 13 de fevereiro de 1995, e revoga a Lei no 6.528, de 11 de maio de 1978. Available from: http://www.planalto.gov.br/ccivil_03/_ato2007-2010/2007/lei/111445.htm. Accessed: 10 ago. 2018.

BRASIL. Ministério da Saúde. Fundação Nacional de Saúde. Manual de Saneamento. 4. ed. Brasília: Funasa, 2015. 
CASTRO, J.E. Políticas públicas de saneamento e condicionantes sistêmicos. In: Heller L.; Castro J.E. (org.). Política pública e gestão de serviços de saneamento. Ed. Ampl. Belo Horizonte: Editora UFMG, 2013; Rio de Janeiro: Editora Fiocruz, 2013. P. 53-75.

. Water governance in the twentieth-first century. In: Ambient. soc., v. 10, n. 2, p. 97-118 jul./dec. 2007 ..

CETESB. Companhia Ambiental do Estado de São Paulo (São Paulo) Qualidade das águas interiores no estado de São Paulo 2017. São Paulo: CETESB, 2018.

DIETZ, T.; OSTROM, E.; STERN, P.C. The Struggle to Govern the Commons. Science. V. 302, n. 5652, p. 1907-1912, dec. 2003.

IBGE - INSTITUTO BRASILEIRO DE GEOGRAFIA E ESTATÍSTICA. Censo demográfico 2010. Instituto Brasileiro de Geografia e Estatística: Rio de Janeiro, 2011.

FRACALANZA, A.P. Crise de governança da água na Região Metropolitana de São Paulo: (re) centralização da gestão e injustiça ambiental. Tese (Livre Docência em Ciências Ambientais - Escola de Artes, Ciências e Humanidades, Universidade de São Paulo, São Paulo, 2017.

FRACALANZA, A.P.; JACOB, A.M.; ECA, R.F. Justiça ambiental e práticas de governança da água: (re) introduzindo questões de igualdade na agenda. Ambient. soc., v. 16, n. 1, p. 19-38, mar. 2013.

GUARULHOS. Lei $\mathrm{N}^{\circ}$ 6.308, de 16 de novembro de 2007. Dispõe sobre a regulamentação do Conselho Municipal de Desenvolvimento Urbano e a criação do Fundo Municipal de Desenvolvimento Urbano. Available from: https://www.guarulhos.sp.gov.br/06_prefeitura/leis/leis download/06308lei.pdf. Accessed: 10 ago. 2018.

GUARULHOS. Decreto N³2.360, de 29 de dezembro de 2014. Regulamenta o

artigo 67, II, da Lei Municipal nº 6253/2007 no que se refere à competência do

Conselho Municipal de Desenvolvimento Urbano para exercer o controle social sobre o serviço público de saneamento básico. Available from: https:/www.guarulhos.sp.gov.br/06_prefeitura/ leis/decretos_2014/32360decr.pdf. Accessed: 10 ago. 2018.

GURGEL, C.; JUSTEN, A. Controle social e políticas públicas: a experiência dos Conselhos Gestores. In: Rev. Adm. Pública, Rio de Janeiro, n. 47, v. 2, p. 357-378, mar./apr. 2013.

HELLER, L. The crisis in water supply: how different it can look through the lens of the human right to water? Cad. Saúde Pública. v. 31, n. 3, p. 447-449, mar 2015

HOPPE, R. Argumentative turn. Science and Public Policy, v. 26, n 3, p. 201-210, jun. 1999.

HOVE, S. van den. Participatory approaches to environmental policy-making: the European Commission Climate Policy Process as a case study. Ecological Economics, v. 33, p. 457-472, 2000. 
IORIS, A. Desenvolvimento Nacional e Gestão de Recursos Hídricos no Brasil. Revista Crítica de Ciências Sociais, v. 85, p. 23-41, 2009.

JACOBI, P. R. Gestão democrática e participativa no saneamento: conceitos e problematização. In: Brasil. Ministério das Cidades. Secretaria Nacional de Saneamento Ambiental. PMSS. Instrumentos das políticas e da gestão dos serviços públicos de saneamento básico. coord. Berenice de Souza Cordeiro. Brasília: MCidades, 2009. p. 103-113.

JACOBI, P.R.; GÜNTHER, W.M.R.; GIATTI, L.L. Agenda 21 e governança. Estud. av. v. 26, n.74, 331-340, 2012.

LAVALLE, A.G.; VERA, E.I. A trama da crítica democrática: da participação à representação e à accountability. Lua Nova, São Paulo, v. 84, p. 353-364, 2011.

MAYNTZ, R. New challenges to governance theory. In: Bang H. P. (Ed). Governance as social and political communication. Manchester, New York: Manchester University Press, 2003.

MOLLINGA, P.P. Water, politics and development: framing political sociology of water resources management. Water alternatives, v.1, n. 1, p. 7-23, 2008.

MORAES, L.R.S. Controle social no saneamento básico - uma contribuição para o debate. In. IV Seminário internacional de engenharia de saúde pública. Belo Horizonte, MG, 2013. Available from: <www.funasa.gov.br/site/wp-content/uploads/2013/05/luiz_roberto.pdf > Accessed: 10 ago. 2018.

PAZ, M.G.A. da; JACOBI, P.R. Integração das Políticas Públicas de Saneamento e Recursos Hídricos na Bacia Hidrográfica Sorocaba e Médio Tietê. In: Encontro da Associação Nacional de Pós-Graduação e Pesquisa em Ambiente e Sociedade, 7., 2015, Brasília, DF. Anais... Brasília: ANPGPAS, 2015.

PITERMAN, A.; HELLER, L.; REZENDE, S.C. (A falta de) Controle social das políticas municipais de saneamento: um estudo em quatro municípios de Minas Gerais. In: Saúde Soc, São Paulo, v.22, n.4, p.1180-1192, 2013.

RAZZOLINI, M.T.P.; GÜNTHER, W.M.R. Impactos na Saúde das Deficiências de Acesso a Água. Saúde Soc., v. 17, n. 1, p. 21-32, 2008.

SNIS - Sistema Nacional de Informações sobre Saneamento. MCidades - Ministério das Cidades. Série Histórica. s.d. SNIS, MCidades. Available from: <www.snis.gov.br/aplicacao-web-serie-historica> Accessed: 10 ago. 2018.

RIBEIRO, W.C. Impasses da governança da água no Brasil. In: Ribeiro, WC (org). Governança da água no Brasil: uma visão interdisciplinar. São Paulo: Annablume; Fapesp; CNPq, 2009. p. 109-133.

SAAE - Serviço Autônomo de Água e Esgoto. Guarulhos. Sistema de Água. s.d. Available from: <http://www.saaeguarulhos.sp.gov.br:8081/sistema-de-agua > Accessed: 10 aug. 2018. 
SNSA - SECRETARIA NACIONAL DE SANEAMENTO AMBIENTAL. Plano Nacional de Saneamento Básico - Plansab. Brasília: Ministério das Cidades, Secretaria Nacional de Saneamento Ambiental, 2013.

SOLANES, M.; JOULAVLEV, A. integrando economía, legislación y administración en la gestión del agua y sus servicios en América Latina y el Caribe. Revista Virtual REDESMA. Mar. Vol. 5, n. 1, p. 22-28, 2011.

WARNER, J. Multi-stakeholder platforms: integrating society in water resource management? Ambient. soc., v. VIII, n. 2, p. 1-20, jul./dez. 2005. 
Mariana Gutierres Arteiro da Paz

曰pazmga@gmail.com

ORCiD: https://orcid.org/0000-0003-3055-6184
Submitted on: 22/03/2019

Accepted on: 10/03/2020

2020;23:e00191

\section{Ana Paula Fracalanza \\ $\square$ fracalan@usp.br}

ORCiD: https://orcid.org/0000-0001-9289-0028

How to cite: PAZ, M. G. A.; FRACALANZA, A. P. Social control in basic sanitation at Guarulhos (SP): the Municipal Council of Urban Policies. Ambiente \& Sociedade. São Paulo, v. 23, p. 1-19, 2020. 


\title{
Controle social no saneamento básico em Guarulhos (SP): o Conselho Municipal de Política Urbana
}

\author{
Mariana Gutierres Arteiro da Paz \\ Ana Paula Fracalanza
}

São Paulo. Vol. 23, 2020

Artigo Original
Resumo: A área de saneamento básico no Brasil tem um histórico centralizador. A instituição da Lei Federal no 11.445, em 2007, propiciou a possibilidade de abertura para a participação e o controle social na área, mecanismos de inclusão de diversos segmentos da sociedade, favorecendo a governança integrativa. $\mathrm{O}$ objetivo deste estudo de caso foi avaliar a incorporação do tema do saneamento básico no Conselho Municipal de Política Urbana do Município de Guarulhos, SP, e avaliar a participação na área segundo os preceitos da justiça ambiental e da governança da água, no período de 2015 a 2017. O Conselho estudado pouco tratou de ações de saneamento básico, mesmo num momento de crise de abastecimento de água, e se pautou, principalmente, em questões relacionadas à revisão do Plano Diretor. A forma como foi atribuída ao Conselho a competência de lidar com as questões de saneamento básico não favoreceu a construção social do processo.

Palavras-chave: controle social, saneamento básico, governança da água.

Como citar: PAZ, M. G. A.; FRACALANZA, A. P. Social control in basic sanitation at Guarulhos (SP): the Municipal Council of Urban Policies. Ambiente \& Sociedade. São Paulo, v. 23, p. 1-20, 2020. 


\title{
Evaluación de control social sobre agua y saneamiento en Guarulhos (SP)
}

\author{
Mariana Gutierres Arteiro da Paz \\ Ana Paula Fracalanza
}

São Paulo. Vol. 23, 2020

Artículo original
Resumen: El sector de agua y saneamiento en Brasil tiene un fondo centralizado. La Ley Federal $n^{\circ} 11.445$, en 2007, brinda la posibilidad de participación y control social en el sector; y mecanismos para la toma de decisiones descentralizada e incluir varios sectores en el sector del agua y el saneamiento para la gobernanza integral. Por lo tanto, este documento tiene como objetivo evaluar la incorporación de agua y saneamiento en el Consejo Municipal de Política Urbana en Guarulhos, SP (2015-2017); y evaluar la participación social según la justicia ambiental y la gobernabilidad del agua. Esta se centra en las reuniones del Consejo. El Consejo estudiado no se ocupó de los temas de agua y saneamiento, incluso durante una crisis de suministro de agua, y las reuniones se basó principalmente en cuestiones relacionadas con la revisión del Plan Director Municipal. La imposición del control social del agua y el saneamiento no contribuyó al proceso de construcción social.

Palabras-clave: control social, agua y saneamiento, gobernabilidad del agua.

Como citar: PAZ, M. G. A.; FRACALANZA, A. P. Evaluación de control social sobre agua y saneamiento en Guarulhos (SP). Ambiente $\mathbb{E}$ Sociedade. São Paulo, v. 23, p. 1-20, 2020.

DOI: http://dx.doi.org/10.1590/1809-4422asoc20190019r1vu2020L4AO 